\title{
Leaf Traits of Drought Tolerance for 37 Shrub Species Originating from a Moisture Gradient
}

\author{
Gui-Qing $X u^{1,2,3, * \mathbb{D}}$, Stefan K. Arndt ${ }^{4}\left(\mathbb{D}\right.$ and Claire Farrell ${ }^{4}$ \\ 1 State Key Lab of Desert and Oasis Ecology, Xinjiang Institute of Ecology and Geography, \\ Chinese Academy of Sciences, Xinjiang 830011, China \\ 2 Fukang Station of Desert Ecology, Chinese Academy of Sciences, Xinjiang 830011, China \\ 3 University of Chinese Academy of Sciences, Beijing 100049, China \\ 4 Department of Ecosystem and Forest Sciences, University of Melbourne, 500 Yarra Boulevard, \\ Richmond, Victoria 3121, Australia; sarndt@unimelb.edu.au (S.K.A.); c.farrell@unimelb.edu.au (C.F.) \\ * Correspondence: xugq@ms.xjb.ac.cn; Tel.: +86-991-7885414
}

Received: 29 April 2020; Accepted: 1 June 2020; Published: 6 June 2020

check for updates

\begin{abstract}
Identifying the drought-tolerance traits of plant species originating from a moisture gradient will increase our understanding of the differences and similarities in plant drought tolerance. However, which traits can be used to evaluate drought tolerance remain an open question. Here, we conducted a common-garden experiment on 37 shrub species originating from desert to humid regions. The correlations between plant traits and the native environmental conditions were studied. Leaf sizes and Huber values were significantly correlated with most climate variables of the shrubs' origins. The osmotic potentials at full turgor $\left(\pi_{100}\right)$, turgor loss point $\left(\Psi_{\mathrm{TLP}}\right)$, and midday leaf water potential $\left(\Psi_{\mathrm{mid}}\right)$ were significantly correlated with most climate variables of their origins. We proposed using leaf sizes, Huber values, and $\Psi_{\mathrm{TLP}}$ as predictors of drought tolerance across shrub species and shrub biomes. Statistically significant correlations were found between $\pi_{100}, \Psi_{\mathrm{TLP}}$, and specific leaf area (SLA). However, owing to the weak correlations between SLA and the climate variables of the shrubs origins and between Huber values and leaf size and turgor loss traits, it was difficult to integrate leaf morphological traits with physiological traits to find a simple way to accurately quantify drought-tolerance-related differences among these shrub species.
\end{abstract}

Keywords: biogeography; climate; drought tolerance; morphological traits; physiological traits

\section{Introduction}

All ecosystems worldwide will be influenced to certain degree by climate change, with forecast for more frequent and severe drought occurrence in the future [1]. Forest dieback caused by drought has been reported in every terrestrial ecosystem in the past few decades [2-4], which may ultimately lead to the collapse of eco-services [5]. The effective protection of existing forests to provide services under these circumstances must involve the cautious consideration of species' capacities to withstand future climatic interferences and acclimation to future climate regimes [6]. Thus, it is crucial to comprehend the function of leaf morpho-physiological traits in facilitating accliantion to extreme heat and drought under predicted climatic changes [6,7]. Identifying the leaf drought-tolerance traits that are positioned on a moisture or aridity gradient may help us further understand the differences in drought tolerance and will assist in characterizing the impact associated with exposure to future climates. This understanding may help us to reveal the species' different vulnerabilities to climate-induced drought and facilitate the development of effective measures to protect forests.

Many morphological and physiological traits are used as indicators of drought tolerance. Leaf morphology or structural traits are linked to mechanisms of desiccation tolerance and thus 
are considered as important traits for assessing drought tolerance [8-12]. For example, leaf mass per area (LMA), leaf thickness, leaf toughness, and wood density were used widely as proxies for drought tolerance, but controversial views on this topic still remain [7,13-15]. Physiological traits are promising markers for drought tolerance as they are strong mechanistic links to water-stress responses $[6,16,17]$. However, the physiological traits also show great intraspecific variation owing to local environmental conditions and phenotypic plasticity [18-20]. Furthermore, there is a possible adaptive connection between leaf structural and physiological traits across multiple biomes [21] and in a few local plant communities $[16,18,22]$ that undergone contrasting levels of water supply. The integration of relatively independent traits better reflects environmental constrains [23], therefore improving the evaluation of ecological drought tolerance capabilities among plant species. Currently, which trait or trait combination better represent drought tolerance remain an open question [13].

Plant water-related traits, such as the leaf osmotic potentials at which stomatal closure, wilting, and hydraulic dysfunction [24-27] are important parameters to evaluate the drought tolerance and drought adaptation of plants [13,28,29]. The traits derived from pressure - volume curves that make plant species adapt to a wide range of habitats and climates are important hydraulic traits and have broad ecological significance with regard to climatic zones $[6,13]$. The negative water potential at which a leaf cell loses turgor (namely, the turgor lost point, $\Psi_{\mathrm{TLP}}$ ) and the leaves wilt, play key roles in sustaining gas exchanges and metabolic activities $[18,25]$ and in characterizing the ability to maintain leaf functions under drought stress. Therefore, it is closely related to plant drought tolerance, and thus species distribution, with respect to moisture conditions [17,27,30-32]. Furthermore, cell-wall elasticity also shows an adaptive significance: greater cell-wall elasticity decreases cell osmotic potential, thereby expanding the water potential gradient and decreasing cell-wall elasticity, resulting in turgor upholding at a shrinking cell volume [18]. Species or biomes of dry origin express lower (more negative) water relation traits compared with those of wet origin $[13,24]$. Despite its potential application for quantifying ecological drought tolerance $[21,25,33,34]$, the broad characterization of the turgor loss point and other water-related traits within and across biomes as an index of drought tolerance has proven to be a challenge. These include the high variability of water-related traits, which may result from confounding environmental factors, variant life forms, or plant functional types, as well as plant traits' plasticity $[13,24]$. Future studies need to verify the relationship between leaf osmotic potentials at the turgor loss point and plant habitats fitness over a wide scope of soil moisture gradient [7].

The above shortcomings may be partly addressed by planting the same life form (namely shrubs) with different climatic origins and maintaining the shrubs under same environmental conditions (in a common garden) [13]. However, the correlations between climate of origin and leaf structure and physiology among shrub species remain unclear owing to the lack of quantitative measurements, which hinders our understanding of the differences in drought resistance of shrubs. In Australia the native shrubs are widely distributed from desert to humid region and have important values for livestock [35] and green roof-related plant selection [36]. Under the context of climate change, the growth and survival of shrub species in Australia is threatened [6,37]. Identifying differences in drought-tolerant traits of shrub species is pressing for understanding the likely fates of current shrub species in the context of climate change. In response to these problems, we selected 37 shrub species growing at the University of Melbourne in Victoria that originated from a moisture gradient. We hypothesized that selective pressures from the species' native climates constrain the genotypes maintained within a species and thus that the drought-tolerant traits of different species are correlated with the climate of the species' distribution range. Our aims were as follows: (1) to determine the correlations between the drought-tolerance traits and the natural distribution site's water availability; and (2) to assess the adaptive links between leaf morphological and physiological traits along the moisture gradient. Based on the differences in rainfall, temperature and aridity, we hypothesized the following: (1) leaf size is negatively correlated with the annual average temperature of the native distribution site and positively correlated with the average annual rainfall and arid index of the native distribution site; (2) Huber values are negatively correlated with site rainfall and the site aridity index; 
and (3) the bulk leaf turgor loss point ( $\left.\Psi_{\mathrm{TLP}}\right)$ is positively correlated with site rainfall and the site aridity index. These results may help us in predicting the performance and distribution of these shrubs in future climates.

\section{Materials and Methods}

\subsection{Site Description}

The common garden experiment was carried out at the Burnley Campus, University of Melbourne, Australia $\left(37^{\circ} 47^{\prime} \mathrm{S} ; 144^{\circ} 58^{\prime} \mathrm{E}\right)$. In this study, we chose 37 shrub species from Australia that were positioned along a rainfall gradient from approximately $300 \mathrm{~mm}$ to $1200 \mathrm{~mm}$ in their natural distribution area (Table 1). Seedlings from commercial nurseries were transplanted between 2009 and 2011 to the Burnley Campus. For each shrub species, the natural distribution occurrence records were obtained from the Atlas of Living Australia (ALA; 2013; Victorian Biodiversity Atlas "FLORA100," 2008). Thus, the selected shrub species experienced identical environmental conditions. To avoid the influence of summer drought on the plasticity of plant traits in the garden, all the traits were measured on winter days from 13 June to 30 June 2016 that having plentiful rainfall.

\subsection{Climate Variables}

We used the ALA to assess the climatic conditions of the observed species' distributions. The species occurrence records come from a scientific collection of specimens and observations by an individual or member of an organization. Only the validated records of species occurrences layers were overlaid with the selected environmental layers and then downloaded from the ALA using the "mapping and analysis" portal. The climatic layers (based on a gridded dataset, $\sim 1 \mathrm{~km} \times 1 \mathrm{~km}$ ) extracted from the environmental layer portal on the ALA. We downloaded mean annual precipitation (MAT), mean annual temperature (MAP), and mean annual aridity index (AI) data for all sampling points across each species distribution within Australia from the ALA [34]. AI values ranged from 0.175 to 1.381 (Table 1). Previous work showed percentile values of climate variables were key limits for plant survival under drought conditions across Australian vegetation types [38]. Thus we used percentile values to characterize relatively "extreme" edges of the species climatic niche. To characterize the dry ends of the MAP, we used a 0.02 percentile value; while to characterize the warm ends of the MAT data, we used a 0.98 percentile value. In order to compare trait differences across the biome with contrasting habitat preferences, the shrub species were divided into subgroups in accordance with the site MAP. Namely, plants receiving annual rainfalls of less than $400 \mathrm{~mm}$, between $400 \mathrm{~mm}$ and $800 \mathrm{~mm}$, and greater than $800 \mathrm{~mm}$ were mainly arid shrubs, woody open shrubs, and wet shrubs under forest trees, respectively.

\section{3. $\Psi_{T L P}$ and Pressure-Volume Traits}

Pressure-volume (P-V) curves were generated for a minimum of four leaves or shoots of each shrub species using the bench-drying method in accordance with Tyree and Hammel [39]. For each species, shoots of six individual trees were cut in the morning and rehydrated in deionized water for $1 \mathrm{~h}$, which proved to be adequate time for the full rehydration of most species [29]. One leaf of each shoot was cut, and its turgid weight was measured. Then, the corresponding water potential was measured in the pressure chamber. If this measurement was less than $-0.1 \mathrm{MPa}$, the leaf was discarded because it had not fully rehydrated. The leaf was set on the bench to slowly dehydrate at the indoor temperature of $22{ }^{\circ} \mathrm{C}$. Leaf weight were measured approximately every 30-60 min until the correlation between $1 / \Psi$ and fresh weight formed a straight line consisting of at least four measurements. The leaf was dried in an oven at $70{ }^{\circ} \mathrm{C}$ for at least $72 \mathrm{~h}$ to get a constant weigh. The sample was then weighed to determine the relative water content (RWC) as follows:

$$
\text { RWC }(\%)=100 \times(F W-D W) /(T W-D W)
$$


where FW, DW, and TW represent the leaf fresh, dry and turgid weights, respectively. The $\Psi_{\mathrm{TLP}}$, osmotic potential at full turgor $(\pi 100)$, and elastic modulus at full turgor $\left(\varepsilon_{\max }\right)$ were derived from the curve of $1 / \Psi$ against RWC using a P-V curve-fitting routine available online (http://landflux.org) that is based on the work of Schulte and Hinckley [40]. Leaf water potential for P-V curves and midday leaf water potential $\left(\Psi_{\mathrm{mid}}\right)$ was determined using a Scholander-type pressure chamber (Soil moisture Equipment Corp., Santa Barbara, CA, USA).

Table 1. Climates of origin for each shrub species grown in the common garden; mean annual precipitation (MAP), mean annual temperature (MAT) with the range, and mean annual heat-moisture index (HMI). Rows are ordered by ascending HMI at the origin of species.

\begin{tabular}{|c|c|c|c|c|c|c|c|}
\hline No. & Family & Genus & Species & AI & $\begin{array}{l}\text { MAP } \\
(\mathrm{mm})\end{array}$ & $\begin{array}{l}\text { MAT } \\
\left({ }^{\circ} \mathrm{C}\right)\end{array}$ & $\begin{array}{c}\text { Median } \\
\text { AI }\end{array}$ \\
\hline 1 & Proteaceae & Grevillea & Grevillea victoriae & 1.381 & $1169(631,2004)$ & 10.77 & 1.189 \\
\hline 2 & Rutaceae & Correa & Correa lawrenceana & 1.345 & $1172(546,2683)$ & 11.38 & 1.296 \\
\hline 3 & Myrtaceae & Leptospermum & Leptospermum petersonii & 0.899 & $1334(614,2360)$ & 17.24 & 0.814 \\
\hline 4 & Araliaceae & Polyscias & Polyscias sambucifolia & 1.019 & $1120(444,2604)$ & 13.77 & 0.902 \\
\hline 5 & Rutaceae & Zieria & Zieria smithii & 0.817 & $1181(278,3742)$ & 16.89 & 0.788 \\
\hline 6 & Fabaceae & Acacia & Acacia phasmoides & 1.337 & $973(614,1200)$ & 12.69 & 1.254 \\
\hline 7 & Fabaceae & Daviesia & Daviesia latifolia & 1.017 & $954(379,2524)$ & 12.22 & 0.893 \\
\hline 8 & Myrtaceae & Leptospermum & Leptospermum polygalifolium & 0.737 & $1113(199,3404)$ & 16.64 & 0.744 \\
\hline 9 & Plantaginaceae & Veronica & Veronica perfoliata & 0.959 & $924(409,2368)$ & 11.19 & 0.806 \\
\hline 10 & Goodeniaceae & Goodenia & Goodenia ovata & 0.905 & $944(196,2524)$ & 13.64 & 0.876 \\
\hline 11 & Rhamnaceae & Pomaderris & Pomaderris discolor & 0.680 & $1002(392,1609)$ & 16.26 & 0.664 \\
\hline 12 & Proteaceae & Grevillea & Grevillea rhyolitica & 1.101 & $938(864,1016)$ & 14.98 & 1.127 \\
\hline 13 & Myrtaceae & Eucalyptus & Eucalyptus alligatrix & 0.743 & $902(459,1312)$ & 13.57 & 0.714 \\
\hline 14 & Asteraceae & Ozothamnus & Ozothamnus diosmifolius & 0.709 & $1024(247,2360)$ & 16.63 & 0.702 \\
\hline 15 & Malvaceae & Lasiopetalum & Lasiopetalum macrophyllum & 0.826 & $895(317,1531)$ & 14.35 & 0.826 \\
\hline 16 & Rutaceae & Boronia & Boronia molloyae & 1.006 & $923(308,1245)$ & 15.89 & 1.002 \\
\hline 17 & Rutaceae & Crowea & Crowea exalata & 0.757 & $884(408,2073)$ & 14.50 & 0.669 \\
\hline 18 & Proteaceae & Adenanthos & Adenanthos barbiger & 0.984 & $891(256,1152)$ & 16.90 & 0.990 \\
\hline 19 & Fabaceae & Indigofera & Indigofera australis & 0.867 & $844(158,2359)$ & 14.69 & 0.887 \\
\hline 20 & Myrtaceae & Darwinia & Darwinia citriodora & 0.579 & $836(335,1124)$ & 17.01 & 0.535 \\
\hline 21 & Fabaceae & Acacia & Acacia amoena & 0.574 & $728(524,1380)$ & 13.68 & 0.485 \\
\hline 22 & Myrtaceae & Thryptomene & Thryptomene saxicola & 0.706 & $712(362,1181)$ & 15.93 & 0.683 \\
\hline 23 & Asteraceae & Cassinia & Cassinia uncata & 0.613 & $779(222,2287)$ & 14.92 & 0.496 \\
\hline 24 & Proteaceae & Grevillea & Grevillea endlicheriana & 0.687 & $763(350,1087)$ & 18.09 & 0.666 \\
\hline 25 & Malvaceae & Thomasia & Thomasia grandiflora & 0.744 & $699(345,1099)$ & 17.35 & 0.781 \\
\hline 26 & Myrtaceae & Micromyrtus & Micromyrtus ciliata & 0.711 & $685(280,2004)$ & 15.31 & 0.718 \\
\hline 27 & Proteaceae & Adenanthos & Adenanthos cuneatus & 0.560 & $643(282,1219)$ & 16.13 & 0.529 \\
\hline 28 & Fabaceae & Acacia & Acacia flexifolia & 0.424 & $577(255,1155)$ & 16.27 & 0.396 \\
\hline 29 & Rutaceae & Correa & Correa glabra & 0.453 & $547(229,1233)$ & 15.28 & 0.424 \\
\hline 30 & Fabaceae & Gastrolobium & Gastrolobium celsianum & 0.487 & $506(312,1039)$ & 16.08 & 0.459 \\
\hline 31 & Rutaceae & Correa & Correa pulchella & 0.422 & $461(275,835)$ & 16.23 & 0.334 \\
\hline 32 & Myrtaceae & Melaleuca & Calothamnus quadrifidus & 0.402 & $501(195,1252)$ & 17.84 & 0.384 \\
\hline 33 & Proteaceae & Grevillea & Grevillea thyrsoides & 0.371 & $476(353,653)$ & 18.71 & 0.398 \\
\hline 34 & Fabaceae & Acacia & Acacia redolens & 0.312 & $397(329,675)$ & 16.24 & 0.298 \\
\hline 35 & Fabaceae & Acacia & Acacia rigens & 0.226 & $323(175,818)$ & 16.94 & 0.214 \\
\hline 36 & Ehretiaceae & Halgania & Halgania cyanea & 0.214 & $329(151,1252)$ & 17.77 & 0.202 \\
\hline 37 & Amaranthaceae & Chenopodium & Rhagodia spinescens & 0.175 & $313(142,1189)$ & 18.56 & 0.176 \\
\hline
\end{tabular}

Median aridity index (AI) was calculated for each species distribution based on all available botanical/locational records.

\subsection{Morphological Measurements}

All the leaves of three small shoots were removed, and the leaf numbers per shoot were recorded. Leaf size was determined by scanning the leaf area with an LI3100 area meter (Li-Cor, Lincoln, Nebraska, USA). Leaf size was calculated as the average of the three repetitions.

Dry weights (DWs) were measured after drying the leaves at $70^{\circ} \mathrm{C}$ for $72 \mathrm{~h}$ in an oven. Specific leaf area (SLA) was calculated as fresh leaf area divided by DW. The SLAs of all the leaves used for leaf size measurement were calculated.

For the Huber values (sapwood to leaf area ratio), the above three small shoots were used. Such small shoots lack heartwood; therefore, the sapwood area was approximated using the total cross-sectional area. The Huber value was then computed using the sapwood to leaf area ratios of all the leaves on the small shoots. 


\subsection{Statistical Analyses}

To calculate the means and standard errors of each data set, descriptive statistics were used. Pearson's moment correlation tests were used to analyzed the correlation between trait data. Differences among leaf size, SLA, Huber values, $\pi_{100}, \Psi_{\mathrm{TLP}}$, and $\varepsilon_{\max }$ of the different subgroups of shrubs were tested using one-way analyses of variance, followed by the post-hoc Tukey's HSD multiple comparison tests. Figures were plotted using Origin 8.0 (Origin Lab Corp., Northampton, MA, USA). All the data analyses were carried out using IBM SPSS Statistics (Ver.22, Armonk, NY, USA).

\section{Results}

\subsection{Mean Climatic Parameters for Each Species}

Climatic parameters for each shrub species ranged between the two extremes of arid and subalpine rainforest environments (Table 1). Among the natural distribution sites of the 37 shrub species, mean annual rainfalls range from $313 \mathrm{~mm}$ to $1334 \mathrm{~mm}$. The AI ranged from 1.381 to 0.175 . The subalpine climate is characterized by high rainfall and low temperature conditions, resulting in a high AI value. For example, Grevillea victoriae distribute in the south-eastern part of New South Wales and the mountain areas of Victoria, Australia, while Correa lawrenceana is found in rainforests and sclerophyll forests in Tasmania, Victoria, New South Wales, and Queensland. Along the moisture gradient, the climate for the provenances of shrub species became hotter and drier, resulting in decreasing AI values. For example, Rhagodia spinescens and Halgania cyanea are found in the arid and semiarid parts of Western Australia (Figure 1).

\subsection{Dependencies of Leaf Size, SLA, and Huber Value on Provenance Climate}

Of the three climatic indices examined, the leaf sizes were significantly greater as MAP and AI values increased and were smaller as MAT values increased (Figure 2a-c). MAT and AI were the best single predictive variables of leaf size. Huber values significantly decreased as MAP and AI values increased (Figure 2h,i). MAP and AI were the best single predictive variable of the Huber value. Huber values partly reflect the water supply and demand balance among shrubs as a result of long-term adaptation to their natural distribution site's water availability. There were weakly positive correlations between Huber values and MAT (Figure 2g). Correlations between SLA and the three climatic indices were not significant (Figure $2 \mathrm{~d}-\mathrm{f}$ ). Thus, SLAs were independent of the three climatic variables. The addition of climatic indicators founded on the dry ends of the species distribution (e.g., MAP, AI, and MAT) did not reinforce the correlations between climatic indicators and morphological traits (data not shown), compared with climatic indicators derived from the means (Figure 2). Summarily, across the whole data set, leaf size and Huber values were closely correlated with the natural distribution's climatic conditions.

\subsection{Dependence of Turgor Loss Traits on the Native Climate}

We observed strong correlations between the site's climatic variables and most water-related parameters. The correlations between $\pi_{100}$ and the site's MAT and AI values were significant (Figure 3a,c). The $\pi_{100}$ decreased as MAT increased and increased along with AI. There were significantly correlations between $\Psi_{\text {TLP }}$ and the three climatic indices (Figure $3 \mathrm{~d}-\mathrm{f}$ ). MAT and AI were the best single predictors of $\Psi_{\text {TLP }} . \Psi_{\text {TLP }}$ decreased as MAT increased and increased as AI decreased. $\Psi_{\text {TLP }}$ increased along with MAP. The midday leaf water potential was also closely correlated with the natural distribution site's MAP and AI (Figure 3k,l). The addition of climatic indicators founded on the dry ends of the species distribution (e.g., MAP, AI, and MAT) did not reinforce the correlations between climatic indicators and physiological traits (data not shown) compared with climatic indicators derived from the means (Figure 3). 

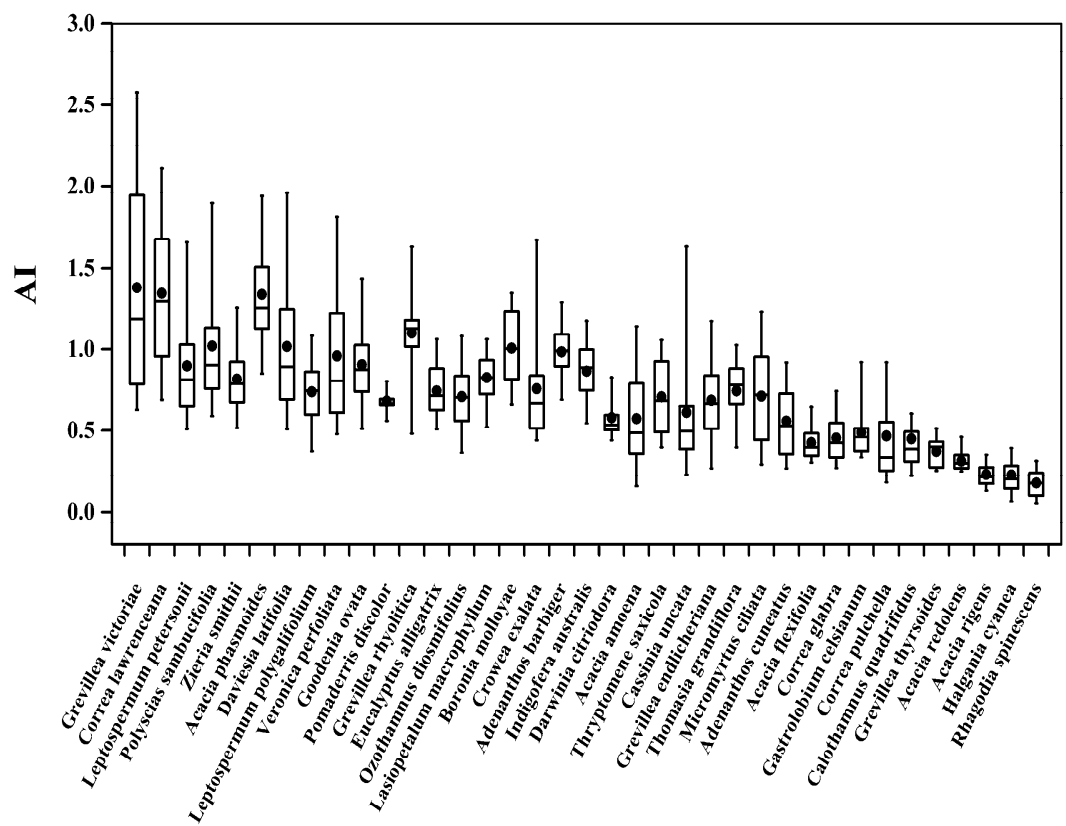

Species

Figure 1. The climatic distributions of 37 shrubs species for all occurrence records in the Atlas of the Living Australia (2013) as represented by the mean annual aridity index (AI). The boxes mark the intervals between the 25 th and 75 th percentiles. The whiskers denote the intervals between the 5 th and 95th percentiles. The solid circle represents the mean, and the line in the box represents the median.

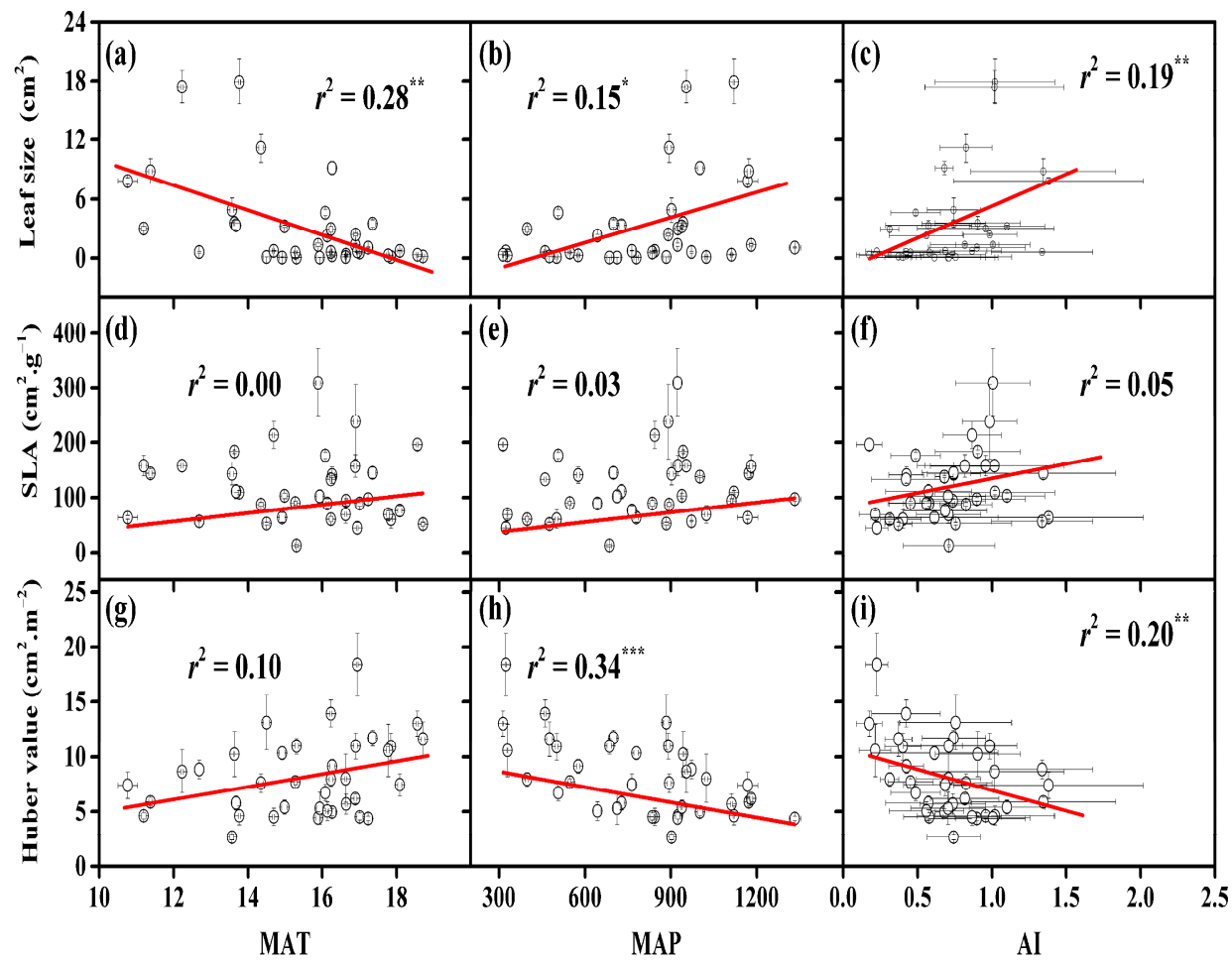

Figure 2. Influence of mean annual temperature (MAT), mean annual precipitation (MAP), and annual aridity index (AI) at each species' natural geographical distribution on $(\mathbf{a}-\mathbf{c})$ leaf size, $(\mathbf{d}-\mathbf{f})$ specific leaf area (SLA), and (g-i) Huber value. The solid curved line represents the nonlinear fitting, and the solid straight lines represents the linear regression. Associated $r^{2}$ values are provided $\left({ }^{*} P<0.05, * * P<0.01\right.$, *** $P<0.001)$. Data are means \pm 1 SE. 


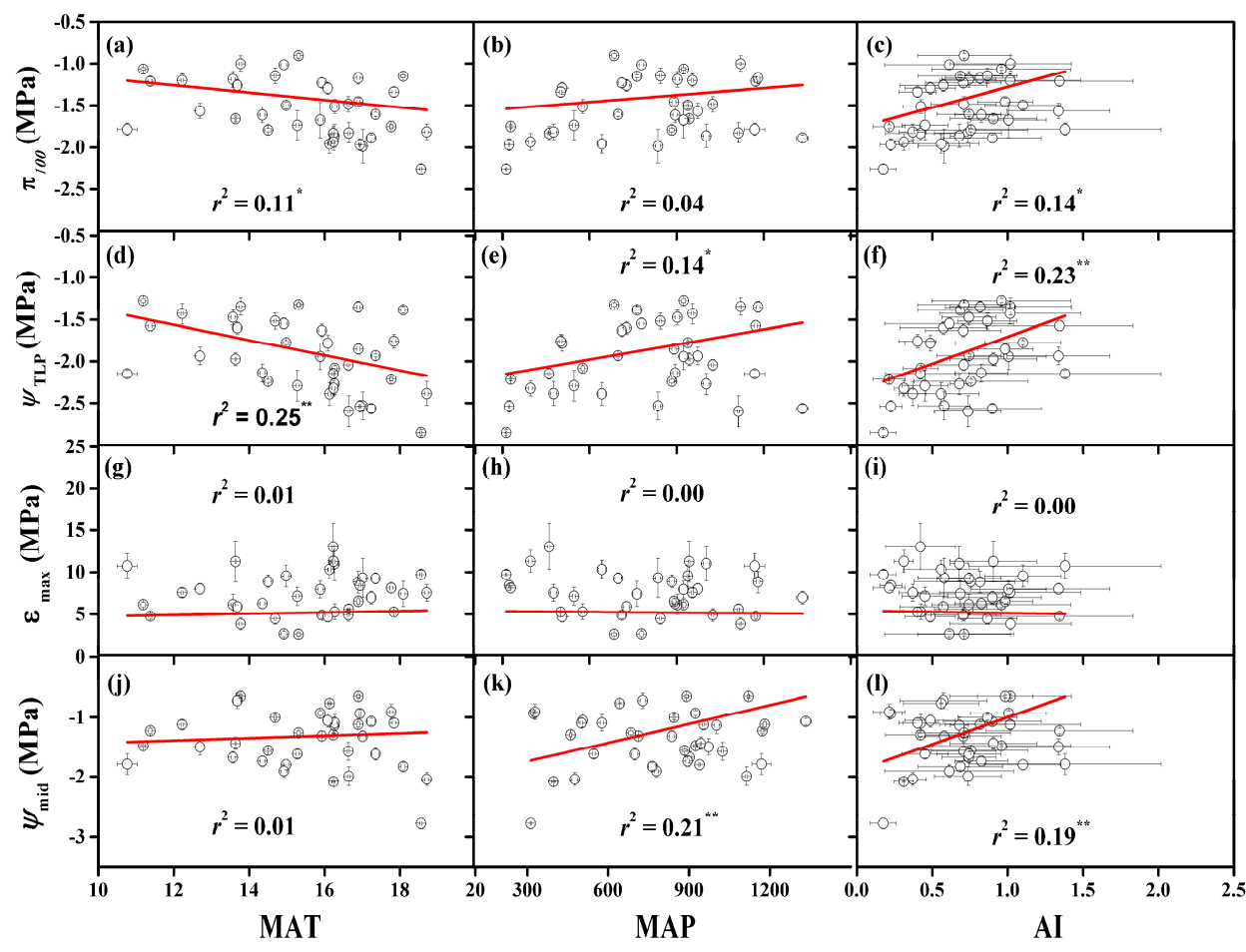

Figure 3. Correlations between each of three traits, annual mean temperature (MAT), mean annual precipitation (MAP), and annual aridity index (AI), at each species' natural geographical distribution and $(\mathbf{a}-\mathbf{c})$ osmotic potential at full turgor $\left(\pi_{100}\right),(\mathbf{d}-\mathbf{f})$ turgor loss point $\left(\Psi_{\mathrm{TLP}}\right),(\mathbf{g}-\mathbf{i})$ modulus of elasticity $\left(\varepsilon_{\max }\right)$, and $(\mathbf{j}-\mathbf{l})$ midday leaf water potential $\left(\Psi_{\text {mid }}\right)$. Solid lines represent the linear regressions and associated $r^{2}$ values are provided $\left({ }^{*} P<0.05,{ }^{* *} P<0.01,{ }^{* * *} P<0.001\right)$. Data are means \pm 1 SE.

\subsection{Correlations between Turgor Loss and Other Leaf Traits}

We discovered a strong positive correlation between osmotic potential at $\pi_{100}$ and $\Psi_{\text {TLP }}$ (Figure 4a). Variation in $\pi_{100}$ values among the 37 shrub species was a significant element in interpreting the variation in $\Psi_{\mathrm{TLP}}$, and there was a positive correlation in wet winters. There were significantly negative correlations among $\pi_{100}, \Psi_{\mathrm{TLP}}$ and $\varepsilon_{\max }$, demonstrating that osmotic and elastic adjustments coordinated among the leaf water-related traits (Figure 4c,d). The positive correlation between $\Psi_{\text {mid }}$ and $\Psi_{\text {TLP }}$ (Figure $4 \mathrm{~b}$ ) indicated that habitat water availability (midday leaf water potential) was also a significant predictor of $\Psi_{\text {TLP }}$. We observed weak correlations between leaf morphological traits and most water-related parameters, except SLA, which was strongly correlated with $\pi_{100}, \Psi_{\mathrm{TLP}}$, and $\varepsilon_{\max }$ (Figure 5).

\subsection{Leaf Water-Related Traits Correlated with Native Climates across Biomes}

We compared species among the following biome categories: arid/desert shrub $(n=4)$, woody open shrub $(n=13)$, and wet shrub under forest $(n=20)$ in a high-altitude mountainous region. Although all the traits varied significantly among biomes (Figure 6), leaf size, Huber value, $\pi_{100}$, and $\Psi_{\text {TLP }}$ values could be used to separate moist from dry biomes. 

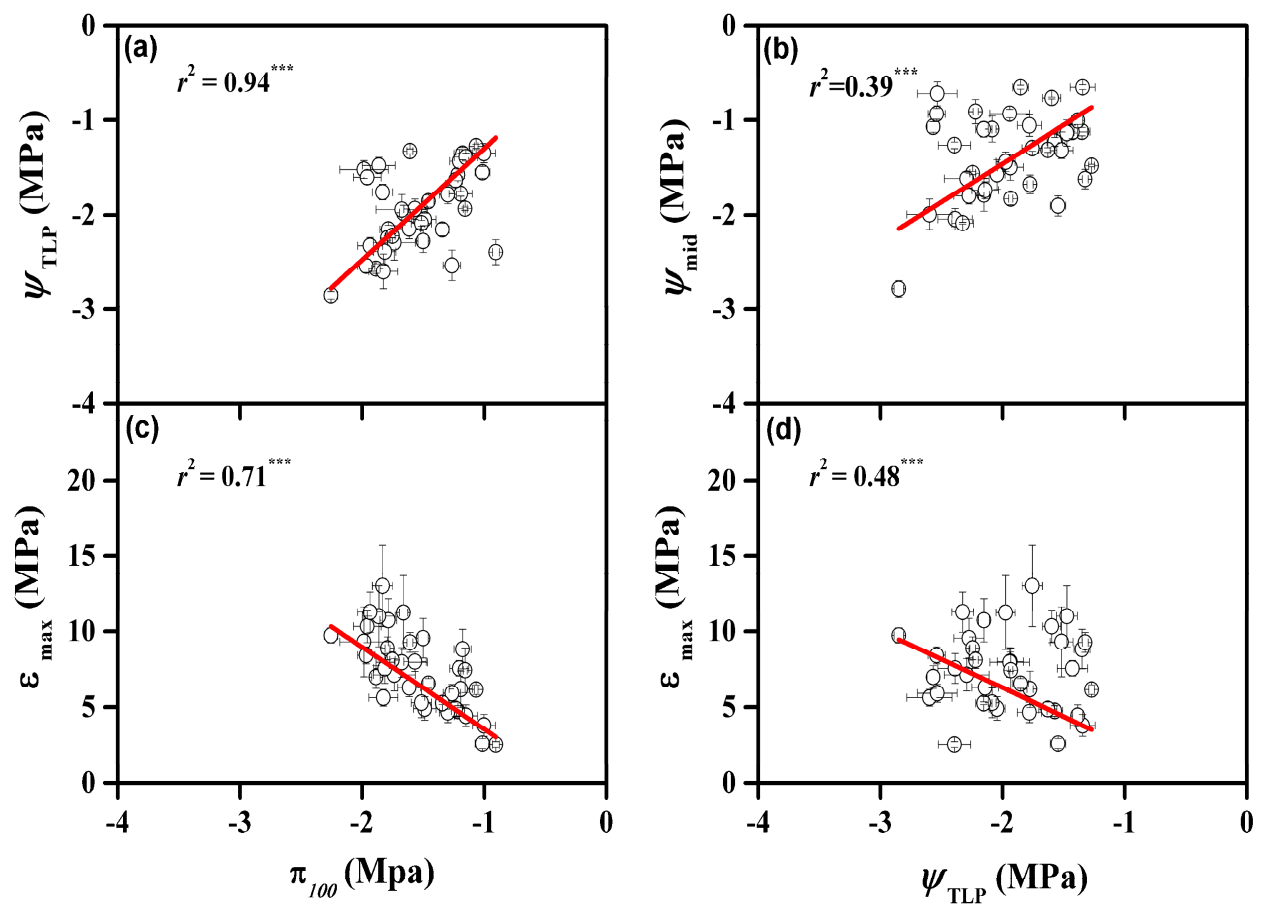

Figure 4. Correlations between osmotic potential at full turgor $\left(\pi_{100}\right)$ and (a) turgor loss point ( $\Psi_{\text {TLP }}$ ) and (c) modulus of elasticity ( $\varepsilon$ max); and the correlations between turgor loss point ( $\Psi$ TLP) and (b) midday leaf water potential $\left(\Psi_{\text {mid }}\right)$ and $(\mathbf{d}) \varepsilon_{\max }$. Solid lines represent the linear regressions, and the associated $r^{2}$ values are provided $\left({ }^{*} P<0.05,{ }^{* *} P<0.01,{ }^{* * *} P<0.001\right)$. Data are means \pm 1 SE.

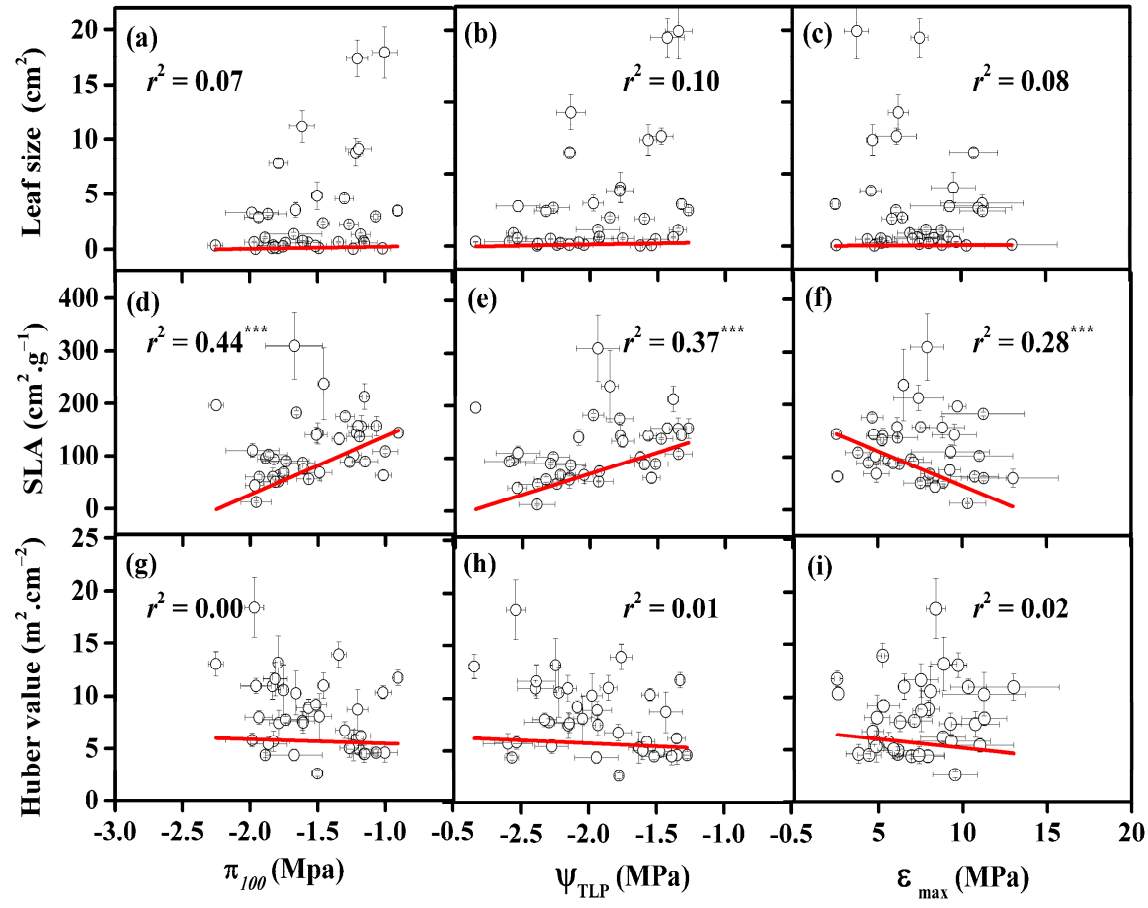

Figure 5. Correlations between each of three traits, osmotic potential at full turgor $\left(\pi_{100}\right)$, turgor loss point ( $\left.\Psi_{\mathrm{TLP}}\right)$ and modulus of elasticity $\left(\varepsilon_{\max }\right)$, and leaf size, specific leaf area (SLA) and Huber value. Solid lines represent the linear regressions, and the associated $r^{2}$ values are provided $\left({ }^{*} P<0.05\right.$, ** $\left.P<0.01,{ }^{* * *} P<0.001\right)$. Data are means \pm 1 SE. 

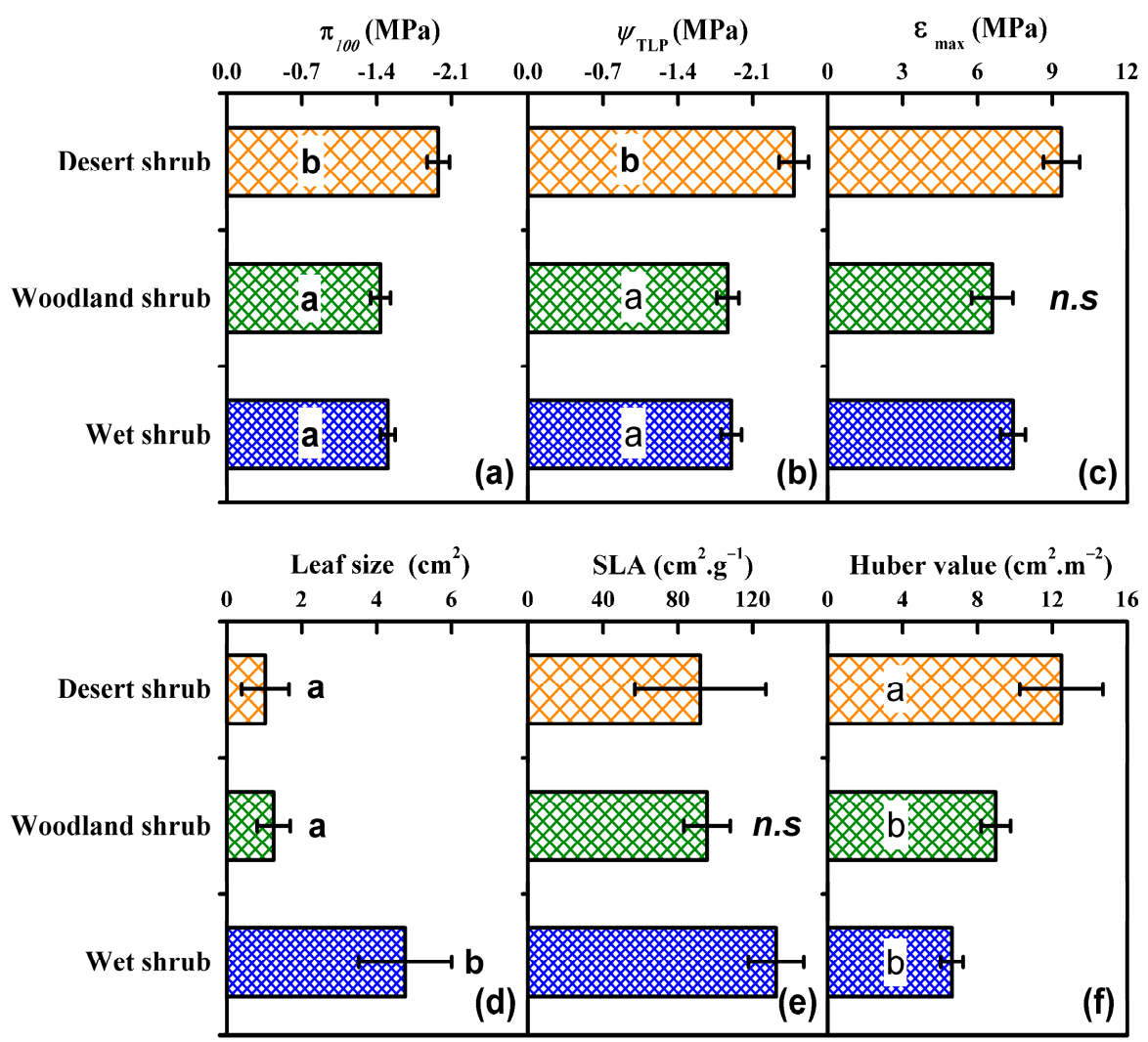

Figure 6. Leaf size, specific leaf area (SLA), Huber values, full turgor $\left(\pi_{100}\right)$, turgor lost point ( $\left.\Psi_{\mathrm{TLP}}\right)$, and modulus of elasticity $(\varepsilon \max )$ represented as means $\pm 1 \mathrm{SE}$ across biome categories. Biome categories: arid/desert shrub $(n=4)$, woody open shrub $(n=13)$, and wet shrub under forest $(n=20)$. Different letters indicate significant differences as assessed by post-hoc Tukey's HSD multiple comparisons $(P<0.05)$.

\section{Discussion}

Increasing drought is a critical challenge for species survive and ecosystems stability; therefore, advanced theory and practices are desired for the quantification of species drought tolerances [8]. An increasing quantity of literature indicated within-species correlations between native climate and leaf morphology and physiology were weak in the common garden [12,41], compare with the persistently more robust correlations among species growing at different sites along a wide moisture gradient $[6,21,23,34,42]$ and even in common closely related garden species [43]. In the current study, 37 shrub species with different climatic origins were planted in a common garden for at least five years before they were used in our experiment. However, the significant correlations between their natural distribution sites' climatic conditions and their morphological and physiological traits demonstrated the strong selective pressure of climatic variables in shaping plant ecophysiological traits among Australian shrub species.

\subsection{The Relevance of Native Climate to Morphological Traits}

The correlations between several leaf attributes and environmental factors, especially water or nutrient availability are generally consistent [44]. The reduction in leaf size as rainfall decreases is often observed [45,46], and this correlation is typically associated with an increase in leaf thickness and a decrease in SLA (leaf area per unit dry mass) [46,47]. However, in our study, SLA showed no synchronous decrease as leaf size decreased (Figure 2a-f). Small leaf size decrease the boundary layer's resistances and facilitate maintaining favorable leaf temperatures and higher photosynthetic water-use efficiencies under high solar radiation and low water availability conditions [48]. Thus, a narrow leaf form or small leaf size is considered as an adaptation to xeric environment [12]. Leaf size across biomes 
differed significantly (Figure 6d). Therefore, in our current study, using leaf size as a predictor of the drought tolerance of shrub species was still practical, as supported by Wright et al. [49].

The SLA usually declines with increasing aridity and nutrient scarcity in native habitats $[46,50]$ because a low SLA is accompanied with drought resistance and also enhances nutrient residence time [51]. The weak correlations between SLA and site climatic variables across plant species were consistent with a study by Niinemets [21] in its inverse measurements (leaf dry mass per unit area). After the rainfall data was $\log 10$-transformed, their study showed a significant linear relationship between SLA and the site's mean monthly precipitation during the three driest months. In our study, owing to the variability in the monthly distributions of rainfall at the native climatic sites of the shrub species [52], we were unable to perform such an analysis. The lack of correlation between SLA and the climate of origin, and no significant difference in SLA across the biome, in our study (Figure 2d-f; Figure 6e) strongly suggested that the wide and untimely use of SLA to forecast species' drought tolerances and distributions is likely to yield misleading results $[7,16]$.

The Huber values of the same or closely related species have been interrelated to climatic gradients, such as precipitation or vapor pressure deficit [53-55]. However, other studies found no correlation between the Huber value and climate of origin or water availability $[26,56,57]$. These contradictory conclusions may be attributed to the plasticity of Huber values. This value can enhance as a result of a decrease of leaf area, which can appear under drought stress. For instance, the Huber value may vary seasonally, increasing during the drought season (water stress or high vapor pressure deficit) [58-60]. We measured the Huber value during the wet winters when the soil water deficit was slight and the vapor pressure deficit was also low, which partly relieved the influence of the plasticity of the Huber value on their relationship. The significantly close correlations between Huber values and MAP and AI in our study strongly supported the first viewpoint in a more broad scope across the different shrub species with the moisture gradient in the common garden (Figure $2 \mathrm{~h}, \mathrm{i}$ ). The Huber values across the biome also showed significant differences (Figure 6f). Thus, we proposed using the Huber value as a predictor of drought tolerance across shrub species and shrub biomes. However, we suggest caution in using Huber values to assess drought-tolerance levels across closely related plant species belonging to the same genus.

Although coherent and universal relationships between most leaf structural traits and native climate variables were found in this case, the explained variances were quite low in some circumstances. Besides the error variance related to climatic data and the plasticity of morphological traits when planting in a common garden, the low universality in climate vs. leaf structure relationships indicates that other plant adaptive traits related to phenology, depth of root systems, and biomass allocation patterns also have important roles in determining the competitive abilities of species with resemble leaf structures along moisture gradients [21].

\subsection{The Importance of Physiological Traits to Ecological Drought Tolerance}

Leaf water potential at wilting $\left(\Psi_{\mathrm{TLP}}\right)$, is a deciding factor of the leaves tolerance to water stress and devotes to plant-level physiological drought tolerance [16]. Leaf turgor loss plays a functional role in driving stomatal closure and hydraulic dysfunction [61,62]. Meanwhile, the leaf water potential at $\Psi_{\mathrm{TLP}}$ is increasingly being used as a robust functional trait to serve as a proxy for ecological drought tolerance across species and vegetation having gradients of site water availability $[6,13,17,28,33,43]$.

The close positive correlations between site climatic variables and $\Psi_{\text {TLP }}($ Figure $3 \mathrm{~d}-\mathrm{f}$ ) indicated that $\Psi_{\text {TLP }}$ is a reliable indicator of a species drought tolerance and could be used to anticipate drought responses. Our study also showed that biomes from dry areas had more negative $\Psi_{\text {TLP }}$ values than those from moisture areas (Figure $6 \mathrm{~b}$ ), and it reinforced the conclusion that $\Psi_{\text {TLP }}$ may imply drought tolerance at the biomes scale [13,42]. Hence, the introduction $\Psi_{\text {TLP }}$ into process-based vegetation models may advance the accuracy of forecast of climate change' influence on shrub species in Australia $[7,63]$. Currently, the use of vapor pressure osmometers, which measure leaf $\Psi_{\text {TLP }}$ rapidly, has overcome the inefficiency and time-consumption of the traditional pressure-volume curve approach [27]. We expect 
the new convenient measuring method to have broad applications in forecasting species reaction to climate fluctuation.

\subsection{Coordination among Morphological and Physiological Traits and Their Correlations with Native Climates}

The close positive correlation between osmotic potential at $\pi_{100}$ and $\Psi_{\text {TLP }}$ (Figure 4a) strongly supported the recent analyses that saturated turgor $\left(\pi_{100}\right)$ is the crucial variable driving $\Psi_{\mathrm{TLP}}$ across shrub species and, thus, that $\pi_{100}$ and $\Psi_{\mathrm{TLP}}$ are robust attributes for forecasting drought tolerance and distributions relating to moisture gradient [13].

There is currently no consensus on whether or not the osmotic or elastic adjustments play a key role in drought acclimation, but increases in $\varepsilon_{\max }$ and decreases in tissue osmotic potential in response to water stress often co-occurred [21]. The negative relationship between osmotic potential at $\pi_{100}$ and $\varepsilon_{\max }$ (Figure $4 \mathrm{~d}$ ) indicates species that mount up solutes (i.e., more negative $\pi_{100}$ ) have rigidity cell walls contrasted with species that have less negative $\pi_{100}$ [18]. The interdependence of $\pi_{100}$ and $\varepsilon_{\max }$ has been verified formerly for several woody species, including Santalum acuminatum (R.Br.) A. DC. (quandong, a shrub), Nuytsia floribunda (Labill.) Fenzi (Western Australian Christmas tree), heath and mallee communities [18], Eucalyptus species [18,64,65], Ziziphus mauritiana Gola [66], and Douglas fir [67]. The larger cell-wall rigidity (higher $\varepsilon_{\max }$ ) in species with higher concentrations of internal cellular solute (lower $\pi_{100}$ ) may be indispensable during fast re-hydration to maintain tissue and cell-wall integrity. Additionally, if the cell walls succumb in response to turgor pressure generated by osmotic accumulation, then the advantages of osmotic adjustment are lost. Similarly, plants that cannot osmotically adjust may profit from elastic walls to sustain positive turgor pressures at lower cell volumes and water contents [18].

Previous studies on SLA and $\Psi_{\text {TLP }}$ under drought stress conditions, involving research on Mediterranean species [68,69], showed no coherent relationship between these attributes. However, these researches were limited to relative few species, and the discrepancy in SLA among those species was minor. In current study, we sampled a various scopes of leaf forms, having a relatively large scope of SLA values $\left(12.22-308.89 \mathrm{~cm}^{2} \mathrm{~g}^{-1}\right)$, and found significant correlations between $\pi_{100}, \Psi_{\mathrm{TLP}}$, and SLA. This result was consistent with the research of Niinemets [21] and Mitchell et al. [18]. Shrub species with lower $\Psi_{\text {TLP }}$ values preferred to have smaller SLAs, which partly ascertains that increased leaf turgor maintenance is combination with more leaf carbon input $[42,69]$. Thus, $\Psi_{\text {TLP }}$ may be used to forecast a species' position along the "fast-slow" plant economic spectrum [42,62]. However, owing to the weak correlation between SLA and the climate variables of the shrub origins, and the weak correlations between Huber values and leaf size and turgor loss traits, it was still difficult to integrated leaf morphological traits with physiological traits to represent ecological drought-tolerance differences among these shrub species. Therefore, our present study did not support the viewpoint that the integration of comparatively unrelated traits (leaf physiological traits vs leaf morphological traits) attains a more precise characterization of their environmental restrictions, as reported by Costa-Saura [23].

\section{Conclusions}

Our study showed that leaf size and Huber values were significant correlated with the climate of the natural distribution site and markedly different between the dry and humid origin shrub biomes. Thus, we proposed the combination of leaf size and Huber value as a predictor of ecological drought tolerance across shrub species and shrub biomes. The close correlations between turgor loss traits and the comprehensive AI suggested that, to a large degree, leaf turgor loss traits were important and have broad ecological significance with regard to climatic zones. $\Psi_{\text {TLP }}$ can be used as an index to characterize the drought-tolerance abilities of shrub species and shrub biomes; thereby, defining the scope of their natural distribution along a moisture gradient. It was still difficult to integrate leaf morphological traits with physiological traits to accurately represent drought-tolerance differences among these shrub species. The morphological and physiological traits may be used to quantify drought tolerance, depending on 
the target concern and the ease of measurement. In spite of the universality of plasticity, $\Psi_{\mathrm{TLP}}$ measured in the wet season in a common garden reliably characterized most shrub species' essential drought tolerances and distributions relation to water availability.

Author Contributions: Conceptualization, S.K.A.; methodology: C.F., and G.-Q.X.; formal analysis, G.-Q.X.; writing-original draft preparation, G.-Q.X.; writing-review and editing, G.-Q.X. All authors have read and agreed to the published version of the manuscript.

Funding: This research was supported by the National Natural Sciences Foundation of China (No. 41730638 and No. U1603105) and the Key Research Program of Frontier Sciences, CAS (QYZDJ-SSW-DQC014).

Acknowledgments: We thank Sanders Gregor for assistance collecting climatic data. Thanks to Christopher Szota, Sanders Gregor, and Lisa Wittick for preparing the pressure chamber and the pressure air.

Conflicts of Interest: The authors declare no conflict of interest.

\section{References}

1. Sheffield, J.; Wood, E.F. Global trends and variability in soil moisture and drought characteristics, 1950-2000, from observation-driven Simulations of the terrestrial hydrologic cycle. J. Clim. 2008, 21, 432-458. [CrossRef]

2. Adams, H.D.; Guardiola-Claramonte, M.; Barron-Gafford, G.A.; Villegas, J.C.; Breshears, D.D.; Zou, C.B.; Troch, P.A.; Huxman, T.E. Temperature sensitivity of drought-induced tree mortality portends increased regional die-off under global-change-type drought. Proc. Natl. Acad. Sci. USA 2009, 106, 7063-7066. [CrossRef] [PubMed]

3. van Mantgem, P.J.; Stephenson, N.L.; Byrne, J.C.; Daniels, L.D.; Franklin, J.F.; Fule, P.Z.; Harmon, M.E.; Larson, A.J.; Smith, J.M.; Taylor, A.H.; et al. Widespread Increase of Tree Mortality Rates in the Western United States. Science 2009, 323, 521-524. [CrossRef] [PubMed]

4. Allen, C.D.; Macalady, A.K.; Chenchouni, H.; Bachelet, D.; McDowell, N.; Vennetier, M.; Kitzberger, T.; Rigling, A.; Breshears, D.D.; Hogg, E.H.; et al. A global overview of drought and heat-induced tree mortality reveals emerging climate change risks for forests. For. Ecol. Manag. 2010, 259, 660-684. [CrossRef]

5. Breshears, D.D.; Lopez-Hoffman, L.; Graumlich, L.J. When Ecosystem Services Crash: Preparing for Big, Fast, Patchy Climate Change. AMBIO 2011, 40, 256-263. [CrossRef]

6. Mitchell, P.J.; O'Grady, A.P. Adaptation of Leaf Water Relations to Climatic and Habitat Water Availability. Forests 2015, 6, 2281-2295. [CrossRef]

7. Delzon, S. New insight into leaf drought tolerance. Funct. Ecol. 2015, 29, 1247-1249. [CrossRef]

8. Hacke, U.G.; Sperry, J.S.; Pockman, W.T.; Davis, S.D.; McCulloh, K.A. Trends in wood density and structure are linked to prevention of xylem implosion by negative pressure. Oecologia 2001, 126, 457-461. [CrossRef]

9. Sack, L.; Cowan, P.D.; Jaikumar, N.; Holbrook, N.M. The 'hydrology' of leaves: Co-ordination of structure and function in temperate woody species. Plant Cell Environ. 2003, 26, 1343-1356. [CrossRef]

10. Bucci, S.J.; Scholz, F.G.; Goldstein, G.; Meinzer, F.C.; Sternberg, L.D.L. Dynamic changes in hydraulic conductivity in petioles of two savanna tree species: Factors and mechanisms contributing to the refilling of embolized vessels. Plant Cell Environ. 2003, 26, 1633-1645. [CrossRef]

11. Lamont, B.B.; Groom, P.K.; Cowling, R.M. High leaf mass per area of related species assemblages may reflect low rainfall and carbon isotope discrimination rather than low phosphorus and nitrogen concentrations. Funct. Ecol. 2002, 16, 403-412. [CrossRef]

12. Warren, C.R.; Tausz, M.; Adams, M.A. Does rainfall explain variation in leaf morphology and physiology among populations of red ironbark (Eucalyptus sideroxylon subsp tricarpa) grown in a common garden? Tree Physiol. 2005, 25, 1369-1378. [CrossRef] [PubMed]

13. Bartlett, M.K.; Scoffoni, C.; Sack, L. The determinants of leaf turgor loss point and prediction of drought tolerance of species and biomes: A global meta-analysis. Ecol. Lett. 2012, 15, 393-405. [CrossRef] [PubMed]

14. Zanne, A.E.; Westoby, M.; Falster, D.S.; Ackerly, D.D.; Loarie, S.R.; Arnold, S.E.J.; Coomes, D.A. Angiosperm wood structure: Global patterns in vessel anatomy and their relation to wood density and potential conductivity. Am. J. Bot. 2010, 97, 207-215. [CrossRef] [PubMed]

15. Fortunel, C.; Ruelle, J.; Beauchene, J.; Fine, P.V.A.; Baraloto, C. Wood specific gravity and anatomy of branches and roots in 113 Amazonian rainforest tree species across environmental gradients. New Phytol. 2014, 202, 79-94. [CrossRef] [PubMed] 
16. Maréchaux, I.; Bartlett, M.K.; Sack, L.; Baraloto, C.; Engel, J.; Joetzjer, E.; Chave, J. Drought tolerance as predicted by leaf water potential at turgor loss point varies strongly across species within an Amazonian forest. Funct. Ecol. 2015, 29, 1268-1277. [CrossRef]

17. Bartlett, M.K.; Zhang, Y.; Kreidler, N.; Sun, S.; Ardy, R.; Cao, K.; Sack, L. Global analysis of plasticity in turgor loss point, a key drought tolerance trait. Ecol. Lett. 2014, 17, 1580-1590. [CrossRef]

18. Mitchell, P.J.; Veneklaas, E.J.; Lambers, H.; Burgess, S.S.O. Leaf water relations during summer water deficit: Differential responses in turgor maintenance and variation in leaf structure among different plant communities in south-western Australia. Plant Cell Environ. 2008, 31, 1791-1802. [CrossRef]

19. Ramírez-Valiente, J.A.; Sánchez-Gómez, D.; Aranda, I.; Valladares, F. Phenotypic plasticity and local adaptation in leaf ecophysiological traits of 13 contrasting cork oak populations under different water availabilities. Tree Physiol. 2010, 30, 618-627. [CrossRef]

20. Peguero-Pina, J.J.; Sancho-Knapik, D.; Barrón, E.; Camarero, J.J.; Vilagrosa, A.; Gil-Pelegrín, E. Morphological and physiological divergences within Quercus ilex support the existence of different ecotypes depending on climatic dryness. Ann. Bot. 2014, 114, 301-313. [CrossRef]

21. Niinemets, U. Global-scale climatic controls of leaf dry mass per area, density, and thickness in trees and shrubs. Ecology 2001, 82, 453-469. [CrossRef]

22. Nardini, A.; Pedà, G.; Rocca, N.L. Trade-offs between leaf hydraulic capacity and drought vulnerability: Morpho-anatomical bases, carbon costs and ecological consequences. New Phytol. 2012, 196, 788-798. [CrossRef] [PubMed]

23. Costa-Saura, J.M.; Martínez-Vilalta, J.; Trabucco, A.; Spano, D.; Mereu, S. Specific leaf area and hydraulic traits explain niche segregation along an aridity gradient in Mediterranean woody species. Perspect. Plant Ecol. Evol. Syst. 2016, 21, 23-30. [CrossRef]

24. Choat, B.; Jansen, S.; Brodribb, T.J.; Cochard, H.; Delzon, S.; Bhaskar, R.; Bucci, S.J.; Feild, T.S.; Gleason, S.M.; Hacke, U.G.; et al. Global convergence in the vulnerability of forests to drought. Nature 2012, 491, 752-755. [CrossRef] [PubMed]

25. Brodribb, T.J.; Holbrook, N.M. Stomatal closure during leaf dehydration, correlation with other leaf physiological traits. Plant Physiol. 2003, 132, 2166-2173. [CrossRef]

26. Choat, B.; Sack, L.; Holbrook, N.M. Diversity of hydraulic traits in nine Cordia species growing in tropical forests with contrasting precipitation. New Phytol. 2007, 175, 686-698. [CrossRef]

27. Bartlett, M.K.; Scoffoni, C.; Ardy, R.; Zhang, Y.; Sun, S.; Cao, K.; Sack, L. Rapid determination of comparative drought tolerance traits: Using an osmometer to predict turgor loss point. Methods Ecol. Evol. 2012, 3, 880-888. [CrossRef]

28. Higgins, S.I.; O'Hara, R.B.; Roemermann, C. A niche for biology in species distribution models. J. Biogeogr. 2012, 39, 2091-2095. [CrossRef]

29. Arndt, S.K.; Irawan, A.; Sanders, G.J. Apoplastic water fraction and rehydration techniques introduce significant errors in measurements of relative water content and osmotic potential in plant leaves. Physiol. Plant. 2015, 155, 355-368. [CrossRef]

30. Abrams, M.D.; Kubiske, M.E.; Steiner, K.C. Drought adaptations and responses in 5 genotypes of Fraxinus pennsylvanica Marsh: Photosynthesis, water relations and leaf morphology. Tree Physiol. 1990, 6, 305-315. [CrossRef]

31. Engelbrecht, B.M.J.; Comita, L.S.; Condit, R.; Kursar, T.A.; Tyree, M.T.; Turner, B.L.; Hubbell, S.P. Drought sensitivity shapes species distribution patterns in tropical forests. Nature 2007, 447, 80-82. [CrossRef] [PubMed]

32. Baltzer, J.L.; Davies, S.J.; Bunyavejchewin, S.; Noor, N.S.M. The role of desiccation tolerance in determining tree species distributions along the Malay-Thai Peninsula. Funct. Ecol. 2008, 22, 221-231. [CrossRef]

33. Lenz, T.I.; Wright, I.J.; Westoby, M. Interrelations among pressure-volume curve traits across species and water availability gradients. Physiol. Plant. 2006, 127, 423-433. [CrossRef]

34. Blackman, C.J.; Gleason, S.M.; Chang, Y.; Cook, A.M.; Laws, C.; Westoby, M. Leaf hydraulic vulnerability to drought is linked to site water availability across a broad range of species and climates. Ann. Bot. 2014, 114, 435-440. [CrossRef] 
35. Revell, D.K.; Norman, H.C.; Vercoe, P.E.; Phillips, N.; Toovey, A.; Bickell, S.; Hulm, E.; Hughes, S.; Emms, J. Australian perennial shrub species add value to the feed base of grazing livestock in low- to medium-rainfall zones. Anim. Prod. Sci. 2013, 53, 1221-1230. [CrossRef]

36. Du, P.; Arndt, S.K.; Farrell, C. Relationships between plant drought response, traits, and climate of origin for green roof plant selection. Ecol. Appl. 2018, 28, 1752-1761. [CrossRef]

37. Guerin, G.R.; Wen, H.; Lowe, A.J. Leaf morphology shift linked to climate change. Biol. Lett. 2012, 8, 882-886. [CrossRef]

38. Mitchell, P.J.; O'Grady, A.P.; Hayes, K.R.; Pinkard, E.A. Exposure of trees to drought- induced die- off is defined by a common climatic threshold across different vegetation types. Ecol. Evol. 2014, 4, 1088-1101. [CrossRef]

39. Tyree, M.T.; Hammel, H.T. The Measurement of the Turgor Pressure and the Water Relations of Plants by the Pressure-bomb Technique. J. Exp. Bot. 1972, 23, 267-282. [CrossRef]

40. Schulte, P.J.; Hinckley, T.M. A comparison of pressure-volume curve data-analysis techniques. J. Exp. Bot. 1985, 36, 1590-1602. [CrossRef]

41. Knutzen, F.; Meier, I.C.; Leuschner, C. Does reduced precipitation trigger physiological and morphological drought adaptations in European beech (Fagus sylvatica L.)? Comparing provenances across a precipitation gradient. Tree Physiol. 2015, 35, 949-963. [CrossRef] [PubMed]

42. Zhu, S.-D.; Chen, Y.-J.; Ye, Q.; He, P.-C.; Liu, H.; Li, R.-H.; Fu, P.-L.; Jiang, G.-F.; Cao, K.-F. Leaf turgor loss point is correlated with drought tolerance and leaf carbon economics traits. Tree Physiol. 2018, 38, 658-663. [CrossRef] [PubMed]

43. Bourne, A.E.; Creek, D.; Peters, J.M.R.; Ellsworth, D.S.; Choat, B. Species climate range influences hydraulic and stomatal traits in Eucalyptus species. Ann. Bot. 2017, 120, 123-133. [CrossRef] [PubMed]

44. Wright, I.J.; Reich, P.B.; Westoby, M.; Ackerly, D.D.; Baruch, Z.; Bongers, F.; Cavender-Bares, J.; Chapin, T.; Cornelissen, J.H.C.; Diemer, M.; et al. The worldwide leaf economics spectrum. Nature 2004, 428, 821-827. [CrossRef]

45. Givnish, T.J. Leaf and Canopy Adaptations in Tropical Forests. In Physiological Ecology of Plants of the Wet Tropics: Proceedings of an International Symposium Held in Oxatepec and Los Tuxtlas, Mexico, June 29 to July 6, 1983; Medina, E., Mooney, H.A., Vázquez-Yánes, C., Eds.; Springer: Dordrecht, The Netherlands, 1984; pp. 51-84. [CrossRef]

46. Fonseca, C.R.; Overton, J.M.; Collins, B.; Westoby, M. Shifts in trait-combinations along rainfall and phosphorus gradients. J. Ecol. 2000, 88, 964-977. [CrossRef]

47. Cunningham, S.A.; Summerhayes, B.; Westoby, M. Evolutionary divergences in leaf structure and chemistry, comparing rainfall and soil nutrient gradients. Ecol. Monogr. 1999, 69, 569-588. [CrossRef]

48. Ackerly, D.; Knight, C.; Weiss, S.; Barton, K.; Starmer, K. Leaf size, specific leaf area and microhabitat distribution of chaparral woody plants: Contrasting patterns in species level and community level analyses. Oecologia 2002, 130, 449-457. [CrossRef]

49. Wright, I.J.; Dong, N.; Maire, V.; Prentice, I.C.; Westoby, M.; Díaz, S.; Gallagher, R.V.; Jacobs, B.F.; Kooyman, R.; Law, E.A.; et al. Global climatic drivers of leaf size. Science 2017, 357, 917-921. [CrossRef]

50. Wright, I.J.; Reich, P.B.; Westoby, M. Strategy shifts in leaf physiology, structure and nutrient content between species of high- and low-rainfall and high- and low-nutrient habitats. Funct. Ecol. 2001, 15, 423-434. [CrossRef]

51. Poorter, H.; Niinemets, U.; Poorter, L.; Wright, I.J.; Villar, R. Causes and consequences of variation in leaf mass per area (LMA): A meta-analysis. New Phytol. 2009, 182, 565-588. [CrossRef]

52. Walter, H.; Breckle, S.-W. The Arid Regions of Australia. In Ecological Systems of the Geobiosphere: 2 Tropical and Subtropical Zonobiomes; Springer: Berlin/Heidelberg, Germany, 1986; pp. 330-365. [CrossRef]

53. Addington, R.N.; Donovan, L.A.; Mitchell, R.J.; Vose, J.M.; Pecot, S.D.; Jack, S.B.; Hacke, U.G.; Sperry, J.S.; Oren, R. Adjustments in hydraulic architecture of Pinus palustris maintain similar stomatal conductance in xeric and mesic habitats. Plant Cell Environ. 2006, 29, 535-545. [CrossRef] [PubMed]

54. Mencuccini, M.; Grace, J. Climate influences the leaf area/sapwood area ration in Scots pine. Tree Physiol. 1995, 15, 1-10. [CrossRef] [PubMed]

55. Magnani, F.; Grace, J.; Borghetti, M. Adjustment of tree structure in response to the environment under hydraulic constraints. Funct. Ecol. 2002, 16, 385-393. [CrossRef] 
56. Edwards, E.J. Correlated evolution of stem and leaf hydraulic traits in Pereskia (Cactaceae). New Phytol. 2006, 172, 479-489. [CrossRef]

57. Vander Willigen, C.; Pammenter, N.W. Relationship between growth and xylem hydraulic characteristics of clones of Eucalyptus spp. at contrasting sites. Tree Physiol. 1998, 18, 595-600. [CrossRef]

58. Eamus, D.; O'Grady, A.P.; Hutley, L. Dry season conditions determine wet season water use in the wet-tropical savannas of northern Australia. Tree Physiol. 2000, 20, 1219-1226. [CrossRef]

59. Macinnis-Ng, C.; McClenahan, K.; Eamus, D. Convergence in hydraulic architecture, water relations and primary productivity amongst habitats and across seasons in Sydney. Funct. Plant Biol. 2004, 31, 429-439. [CrossRef]

60. O'Grady, A.P.; Cook, P.G.; Eamus, D.; Duguid, A.; Wischusen, J.D.H.; Fass, T.; Worldege, D. Convergence of tree water use within an arid-zone woodland. Oecologia 2009, 160, 643-655. [CrossRef]

61. Blackman, C.J.; Brodribb, T.J.; Jordan, G.J. Leaf hydraulic vulnerability is related to conduit dimensions and drought resistance across a diverse range of woody angiosperms. New Phytol. 2010, 188, 1113-1123. [CrossRef]

62. Blackman, C.J. Leaf turgor loss as a predictor of plant drought response strategies. Tree Physiol. 2018, 38, 655-657. [CrossRef]

63. White, D.A.; Turner, N.C.; Galbraith, J.H. Leaf water relations and stomatal behavior of four allopatric Eucalyptus species planted in Mediterranean southwestern Australia. Tree Physiol. 2000, 20, 1157-1165. [CrossRef] [PubMed]

64. Ngugi, M.R.; Doley, D.; Hunt, M.A.; Dart, P.; Ryan, P. Leaf water relations of Eucalyptus cloeziana and Eucalyptus argophloia in response to water deficit. Tree Physiol. 2003, 23, 335-343. [CrossRef] [PubMed]

65. Clifford, S.C.; Arndt, S.K.; Corlett, J.E.; Joshi, S.; Sankhla, N.; Popp, M.; Jones, H.G. The role of solute accumulation, osmotic adjustment and changes in cell wall elasticity in drought tolerance in Ziziphus mauritiana (Lamk). J. Exp. Bot. 1998, 49, 967-977. [CrossRef]

66. Joly, R.J.; Zaerr, J.B. Alteration of cell-wall water content and elasticity in Douglas-fir during periods of water deficit. Plant Physiol. 1987, 83, 418-422. [CrossRef]

67. Salleo, S.; Gullo, M.A.L. Sclerophylly and plant water relations in 3 Mediterranean Quercus species. Ann. Bot. 1990, 65, 259-270. [CrossRef]

68. Corcuera, L.; Camarero, J.J.; Gil-Pelegrín, E. Functional groups in Quercus species derived from the analysis of pressure-volume curves. Trees 2002, 16, 465-472. [CrossRef]

69. Villagra, M.; Campanello, P.I.; Bucci, S.J.; Goldstein, G. Functional relationships between leaf hydraulics and leaf economic traits in response to nutrient addition in subtropical tree species. Tree Physiol. 2013, 33, 1308-1318. [CrossRef]

(C) 2020 by the authors. Licensee MDPI, Basel, Switzerland. This article is an open access article distributed under the terms and conditions of the Creative Commons Attribution (CC BY) license (http://creativecommons.org/licenses/by/4.0/). 